\title{
Role of renewables in strategies of oil companies from Central and Eastern Europe
}

\author{
A. Ilic \\ Postgraduate student, Saint Petersburg Mining University, St. Petersburg, Russia \\ T.V. Ponomarenko \\ Doctor of economics, Professor, Saint Petersburg Mining University, St. Petersburg, Russia
}

\begin{abstract}
This paper deals with the role of renewables in strategies of oil companies from Central and Eastern Europe (CEE) in the process of energy transition. In particular, we analyze whether and to which extent CEE oil companies focus on renewables; if focus, what are the main area of renewable investments; and if focus, is there linkage between their position in oil upstream and investments in renewables. Our research showed that so far activities of CEE oil companies in renewables have been relatively weak, but, under the assumptions that announced projects will be realized, (1) level of investment in renewables of CEE companies in the future will be relatively significant, (2) there are strong differences among CEE oil companies in terms of the significance of renewable productions, (3) those oil companies with relatively weak upstream (crude oil reserves and production) are more interested in renewables and (4) production of electricity from wind and solar dominates the renewable activities of CEE oil companies.
\end{abstract}

Keywords: oil companies, strategy, CEE, renewables, wind farm, solar power plant, biofuels

\section{INTRODUCTION}

Energy transition, defined by the International Renewable Energy Agency (IRENA) as "a pathway toward transformation of the global energy sector from fossil-based to zero-carbon by the second part of this century", has strong implication on oil companies to the extent that the International Energy Agency (IEA) in their recent report (IEA, 2020) stress that no energy company will be unaffected by this transition. In the process of energy transition or so called "decarbonization" one of the key roles rests on production of renewables since renewable energy and energy efficiency measures can potentially achieve $90 \%$ of the required carbon change.

The process of energy transition is spurred by the regulatory changes such as the Paris Agreement (according to the agreement 170 countries agreed to work on bringing climate change under control by limiting the global temperature rise in this century well below 2 degrees Celsius which will demand new in-vestments in low-carbon energy sources) and different incentive schemes imposed by governments to increase production of renewables and reduction of technology costs of renewable energy production. For example, according to IRENA, 2019 the global weighted-average cost of onshore wind projects fell from \$85/MWh in 2010 to $\$ 56 / \mathrm{MWh}$ in 2018 , while the weighted-average cost of utility-scale solar has fallen from $\$ 371 / \mathrm{MWh}$ in 2010 to $\$ 85 / \mathrm{MWh}$ in 2018 and is expected to fall further.

As a result of this processes, global energy demand for renewables reached in 201778 quadrillion British thermal units (QBTU) increasing by $21 \%$ comparing to 2010 , while in the same period demand for oil, gas, and coal grew by 10\%, 12\%, and 5\%, respectively (ExxonMobil, 2019). Demand for renewables is likely to be the key driver of the growth of global energy 
demand in the future, estimated to reach 115 QBTU by 2040 with growth of $47 \%$ comparing to 2017 , while in the same period oil, gas and coal are likely to grow by $14 \%, 36 \%$, and $-9 \%$, respectively. In the group of renewable energy, solar, wind and biofuels are likely to grow the most.

Although the role of renewables is expected to be strong, oil is likely remain the most important global fuel with the share in global energy demand of 30\% (reduction from $32 \%$ in 2017), while the renewables will account to $17 \%$ (increase from $14 \%$ in 2017). Share of coal will be reduced from $26 \%$ to $20 \%$, while the share of gas is likely to increase from $23 \%$ to $20 \%$. This is in line with conclusion of (West \& Fattough, 2019) who argue that, based on their projections, demand for oil and gas will remain robust well after 2050, due to the fact that, even in the case of substantial increase of investments in solar and wind to USD 1trn per annum (from USD 300bn), it will take 55 years for solar and wind to ramp up to $50 \%$ of the world's energy mix.

In such an environment one of strategic dilemmas for an oil company is how to approach this issue, particularly whether to enter this business segment and, if yes, to which extent. In such circumstances some of the reasons why they would enter this business segment are pressure from local governments and shareholders, keeping up with technology - risk of being left behind new energy revolution, fighting with substitutes since electricity suppling electric vehicles pose a long term treat to the industry, finding the new areas for growth and other.

In this paper we deal with strategies of oil companies toward renewables. Since the literature on role of renewables in strategies of global oil companies is relatively reach, we will focus on the analysis of the importance of this business segment in strategies of oil companies from Central and Eastern Europe (Central and Eastern Europe usually includes countries of former the Eastern Bloc: Poland, Czech Repub-lic, Slovakia, Hungary, Romania, Bulgaria, Serbia, Slovenia, Croatia, Bosnia and Herzegovina, Monte-negro, North Macedonia, Albania, Estonia, Latvia and Lithuania. Due to the close proximity and strong focus of business activities on CEE, we include in analysis two more countries - Austria and Greece and its largest oil companies OMV and Hellenic Petroleum). In the part two we provide the analysis of the recent research in this area with special focus on the importance of renewables in strategies of major oil companies. In the part three we introduce the methodology of the research and the sample of analyzed companies. In the part four we provide results with special focus on the relationship between the strength of companies' upstream oil segment and their interest in renewables and in the final part we conclude the research.

\section{LITERATURE REVIEW}

International Energy Agency (IEA, 2020) identifies four possible strategies options for oil companies in energy transition: (1) continuing with traditional oil and gas operations, (2) the use of CCUS technologies (carbon capture, utilization and storage) to bring down emissions, (3) focusing on to supply low-carbon liquids and gases to consumers, and (4) the transition from "fuel“ to „energy“ company, with supply of electricity and other energy services as a part of a diversified offering. Points (3) and (4) relate to renewable production where by low-carbon liquids and gases many consider biofuels based on biomass (for example, wood or crops) such as bioethanol or bio-methane, but also hydrogen, while transition to energy company mostly assumes putting larger focus on renewables in different segments: power production, power trading, electric mobility (e.g. electric vehicle charging), energy storage (production of lithium-ion batteries to power electric vehicles) and other.

Carbon dioxide sequestration technologies in the oil and gas industry are seen as one of the the very important pillars of energy transition. For, example carbon capture and storage (CCS) is a technology enabling to use fossil fuels in a sustainable way. Cherepovitsyn \& Ilinova (2016) indicate that promotion of the technology of carbon dioxide sequestration by means of capturing and injecting it into the underground reservoirs is a promising mechanism of reducing carbon dioxide (CO2) concentration, while (Illinova et al. 2018) point out that CO2 utilizing technologies are circular business models connected with the usage of emissions for providing added benefits 
throughout the value chain and lead to significant ecological, economic and social benefits. Romasheva et al. (2018) showed that the global portfolio of CCS projects is still expanding and developing in a flexible manner and that in some countries, advanced centers are created with the support of the government to promote sequestration technologies where various companies reveal information on the specifics of projects from a process, economic, social, etc. viewpoints. However, (Tcvetkov et al. 2019) stress that although this technology attracts much attention from the industrial sector, government authorities and scientific community, public awareness of the technology is still extremely low. According to (Romasheva \& Ilinova, 2019) coordinated efforts to succeed in CCS activities, as well as the participation of all stakeholders, in particularly government, are needed. Since the implementation of those technologies is not only question at the company level, authors have come to conclusion that aspects such as the planning and programming of CCS activities at the state level, stable financial support, clear legislation, public outreach, and adequate country-specific taxation and crediting are critical to CCS technologies propagation.

Especially interesting strategic option is the transition of an oil company from "fuel" to "energy" company since it assume a substantial change of business model and corporate philosophy. On the individual level there are different examples including extremes on both sides - from staying only exclusively oil company without renewables in portfolio to fully becoming renewable energy company. For example, Danish company Ørsted, formerly DONG Energy (Dansk Olie og Naturgas), experienced full strategic transformation from leading oil and gas company to becoming a leader in renewables without oil and gas production in portfolio since in 2017 divested its oil and gas assets (IEA, 2020). Norway's oil and gas company Equinor is another example of oil company strongly focusing on renewables. The company has recently started with substantial investment cycle in renewables and also changed the name in order to additionally stress these strategic changes. By 2020 Equinor plans to invest into renewables $15-20 \%$ of total investments (Pickl, 2019).

On the other extreme, there are some oil companies without presence in renewables or their presence is symbolic. For example, (Pickl, 2019) indicates that ExxonMobil, one of seven major oil companies, "has shown no interests in renewables, resulting in criticism from climate activists". In addition, there are oil companies that entered renewable business segment, but decided to exit it such as Chevron, another oil major company, who established presence in renewables in the beginning of 2000s, but decided to divest their renewables portfolio in 2014 and 2016, stating as the reason lower returns compared to core activities. The same approach has been recently taken by the Brazilian company Petrobras.

Between the two extremes, there are companies still focusing on their core activities, but with increased share of renewables. According to (Pickl, 2019) Royal Dutch Shell, Total, BP, Eni, and Equinor are in their transition process from oil to energy companies, with Total being the leader in the process with the highest score. In addition, he demonstrated linkage between the oil major's proved oil reserves and their renewable energy strategies indicating that those with lower proved reserves are more oriented to renewables.

Overall, it seems that the role of renewables in strategy of oil companies is growing, but is still relatively weak in spite of increased investments. For example (Zhong \& Bazilian, 2018) claim that "international oil companies (IOCs) have become substantive players in the renewables market, lending their scale and business expertise to deploying clean energy" and investing hundreds of millions of dollars in renewables. However, in spite of hundreds of millions of dollars of investments, the share of investment in renewables is still relatively low compared to the other investments, with some oil companies being very passive in expanding their renewable portfolio, see (Zhong \& Bazilan, 2018) and (Pick1, 2019). This is confirmed by the recent research of the International Energy Agency (IEA, 2020) indicating that investments in lowcarbon businesses represent less than $1 \%$ of oil and gas companies' capital expenditure. Based on this research (Table 1) total value of investments in low-carbon business of major oil companies in 2019 accounted for USD $2.1 \mathrm{bn}$, mostly in the solar and wind renewable energy.

Research of (Csomos 2014) stresses weak role of major oil companies in renewables indicating that "certain companies firmly deny investments in the renewable sector (because of the lower-than-expected returns), while others superficially address them". According to him there is only one company - the France-based supermajor oil company Total - that has 
Table 1. CAPEX on new projects outside oil and gas by large companies [USD bn].

\begin{tabular}{llllll}
\hline & 2015 & 2016 & 2017 & 2018 & 2019 \\
\hline Solar PV & 0.6 & 0.6 & 0.5 & 0.7 & 1.1 \\
Offshore wind & 0.3 & 0.4 & 0.4 & 0.4 & 0.4 \\
Onshore wind & 0.2 & 0.3 & 0.4 & 0.3 & 0.4 \\
CCUS* & 0.4 & 0.2 & 0.2 & 0.3 & 0.1 \\
Biofuels & 0.0 & 0.1 & 0.2 & 0.2 & 0.1 \\
\hline Total & $\underline{1.5}$ & $\underline{1.6}$ & $\underline{1.7}$ & $\underline{1.9}$ & $\underline{0.7} \%$ \\
\hline$\underline{\text { \%of total CAPEX }}$ & $\underline{0.4 \%}$ & $\underline{0.7 \%}$ & $\underline{0.7} \%$ & $\underline{0.8} \%$ \\
\hline
\end{tabular}

Source: IEA (2019)

* CCUS - carbon capture, utilization and storage

globally important renewable energy business. On the other hand, based on the general descriptive analysis (Zhong \& Bazilan, 2018) concluded that results of renewable strategies of oil companies were mixed, with investment models being still emerging.

In summary, review of recent researches show that: 1) investments in renewables of global oil companies increase, 2) in spite of the increase share of investments in total investments is low, below $1 \%$, on average, 3 ) there is difference in significance of renewables in portfolio with some extreme situations and 4) those companies with lower proved oil reserves are likely to be more interested in renewables.

\section{RESEARCH METHODS AND MATERIALS}

In this paper we analyze role of renewables in strategies of oil companies from Central and Eastern Europe with special focus on these questions: 1) whether and to which extent CEE oil companies have renewables as a business segment, 2) if have, what are the main area of renewable investments and 3) if have, is there linkage between their position in oil upstream and investments in renewables. Given the low level of activities of CEE companies in the segment CCUS, we excluded it from the analysis.

Sample of our research consists of eight Central and Eastern European (CEE) companies: PKN Orlen, OMV, MOL, Hellenic Petroleum, OMV Petrom, INA, Petrol and NIS, diversified in terms of the size, business model, ownership structure and geographical presence and, as such, serves as a good analytical foundation. Selected companies are important market players in 12 countries (by important market player, we mean that company has oil refinery in that country or/and has market share of $>10 \%$ in retail market for oil derivatives): Poland (PKN Orlen), Czech Republic (PKN Orlen through its related company Unipetrol), Slovakia (PKN through its related company Unipetrol and MOL through its related company Slovnaft), Lithuania (PKN Orlen through its related company Orlen Lietua, former Mažeiku Nafta), Austria (OMV), Hungary (MOL), Slovenia (Petrol), Croatia (INA), Romania (OMV Petrom), Greece (Hellenic Petroleum), Serbia (NIS) and Bosnia and Herzegovina (INA, NIS, OMV). These countries cover $89 \%$ of CEE region in terms of population. All relevant information are taken from the companies' annual reports and other documents, including public releases, from the official websites.

Based on the descriptive and empirical statistics we analyze renewables strategies of CEE oil companies and with the correlation analysis we evaluate the strength of relationship between their interests in renewables and their level of oil self-sufficiency.

\section{RESULTS AND ANALYSIS}

Activities of oil companies from Central and Eastern Europe are analyzed in three categories: renewables power production, biofuels production and electric mobility (Table 2). 
Table 2. Activities in renewables of CEE oil companies.

\begin{tabular}{|c|c|c|c|}
\hline Company & Power production & Biofuels & Electric mobility \\
\hline PKN Orlen, Poland & $\begin{array}{l}\text { - Acquired license to } \\
\text { build off-shore wind } \\
\text { farm in Baltic Sea with } \\
\text { capacity of } 1,200 \mathrm{MW}\end{array}$ & $\begin{array}{l}\text { - Acquired license to } \\
\text { construct commercial } \\
\text { plant for the produc- } \\
\text { tion of cellulosic etha- } \\
\text { nol from agricultural } \\
\text { residues } \\
\text { - Analyzing possibilities } \\
\text { to deploy advanced } \\
\text { hydrotreated vegetable } \\
\text { oil (HVO) and used } \\
\text { cooking oil (UCO) } \\
\text { technologies at its } \\
\text { plant in Płock }\end{array}$ & $\begin{array}{l}\text { - Planning to invest in } \\
250 \text { electric vehicles } \\
\text { charging stations } \\
\text { (EVCSs) }\end{array}$ \\
\hline OMV, Austria & $\begin{array}{l}\text { - Entered in strategic } \\
\text { partnership with Ver- } \\
\text { bund to build photo- } \\
\text { voltaic plant capacity } \\
\text { of } 16 \mathrm{MW}\end{array}$ & $\begin{array}{l}\text { - No specific actions } \\
\text { announced }\end{array}$ & $\begin{array}{l}\text { - As a minority owner } \\
\text { of SMATRICS }(40 \%) \text {, } \\
\text { has } 435 \text { EVCSs }\end{array}$ \\
\hline MOL, Hungary & $\begin{array}{l}\text { - In } 2018 \text { began to build } \\
\text { solar power plants in } \\
\text { three Hungarian sites } \\
\text { with a total capacity } \\
\text { of } 18.4 \mathrm{MW} \\
\text { - Planning development } \\
\text { of geothermal power } \\
\text { plant with capacity of } \\
\text { 3.8 MW }\end{array}$ & $\begin{array}{l}\text { - No specific actions } \\
\text { announced }\end{array}$ & $\begin{array}{l}\text { - Planning to invest in } \\
150 \text { electric vehicles } \\
\text { charging stations }\end{array}$ \\
\hline $\begin{array}{l}\text { Hellenic Petroleum, } \\
\text { Greece }\end{array}$ & $\begin{array}{l}\text { - Currently poses solar } \\
\text { power plants with cap- } \\
\text { acity of } 19 \mathrm{MW} \text { and } \\
\text { wind farm with cap- } \\
\text { acity of } 7 \mathrm{MW} \\
\text { - Plan to invest in } \\
\text { renewables with cap- } \\
\text { acity of } 300 \mathrm{MW}\end{array}$ & $\begin{array}{l}\text { - No specific actions } \\
\text { announced }\end{array}$ & $\begin{array}{l}\text { - No specific actions } \\
\text { announced }\end{array}$ \\
\hline $\begin{array}{l}\text { OMV Petrom, } \\
\text { Romania }\end{array}$ & $\begin{array}{l}\text { - In } 2017 \text { sold Doro- } \\
\text { bantu wind park with } \\
\text { capacity of } 45 \mathrm{MW} \\
\text { - No further specific } \\
\text { actions announced }\end{array}$ & $\begin{array}{l}\text { - No specific actions } \\
\text { announced }\end{array}$ & $\begin{array}{l}\text { - No specific actions } \\
\text { announced }\end{array}$ \\
\hline INA, Croatia & $\begin{array}{l}\text { - Planning two solar } \\
\text { power plants with cap- } \\
\text { acity of } 11 \mathrm{MW}\end{array}$ & $\begin{array}{l}\text { - No specific actions } \\
\text { announced }\end{array}$ & $\begin{array}{l}\text { - No specific actions } \\
\text { announced }\end{array}$ \\
\hline Petrol, Romania & $\begin{array}{l}\text { - Has renewables cap- } \\
\text { acities of } 32 \mathrm{MW} \\
\text { mostly in wind and } \\
\text { hydro segments } \\
\text { - Planning to increase } \\
\text { capacities by add- } \\
\text { itional } 20 \mathrm{MW}\end{array}$ & $\begin{array}{l}\text { - No specific actions } \\
\text { announced }\end{array}$ & $\begin{array}{l}\text { - By September } 2019 \\
\text { providing charging } \\
\text { services at } 130 \text { EVCSs }\end{array}$ \\
\hline NIS, Serbia & $\begin{array}{l}\text { - Started construction } \\
\text { of wind farm with cap- } \\
\text { acity of } 102 \mathrm{MW}\end{array}$ & $\begin{array}{l}\text { - No specific actions } \\
\text { announced }\end{array}$ & - One EVCS \\
\hline
\end{tabular}

Annual reports and official statements of selected companies 
Until 2020 role of renewables in business of CEE oil companies was relatively weak. Only Petrol (32 MW) and Hellenic Petroleum (26 MW) currently have installed capacities for production of electricity from renewable sources, while NIS has recently started a substantial investment in this segment. OMV, through its subsidiary OMV Petrom, sold its wind farm in 2017 in order to focus on the core business, while MOL and their related company INA plan symbolic investments in renewable power production.

So far, PKN Orlen has not been very active in renewables, but recent announcements indicate change in their strategy - they are now in the process of analyzing possibilities to construct off-shore wind farm in the Baltic See with capacity 1,200 MW, for which have already acquired the license. This can be regarded as a natural step for further development given the fact that the company has strong presence in power generation (total installed capacities of $1,871 \mathrm{MW}$ ) which accounts to $15 \%$ of EBITDA. In addition, the company acquired license to construct bioethanol factory and has plans for development of electric mobility business segment.

In terms of relative significance of renewables for total business one of the good example is Petrol from Slovenia. Currently, production of electricity from renewables accounts for 3\% of the company's EBITDA, while the plan for 2022 is to have $8 \%$ of EBITDA coming from renewables. In general, the company is very active in business activities other than oil, with strong presence in gas distribution and energy efficiency solutions and their activities in renewables are in the direction for becoming fully diversified energy company.

Serbian company NIS has recently started development of wind farm with capacity of 102 MW worth 140 million of euros, which is a relatively substantial investment for the company investing around 300 million of euros yearly on average. However, it is yet to be seen whether this move is step of strategic positioning in renewables or only opportunistic approach taking advantage of opportunities in the Serbian renewable market due to favorable government's incentives through stimulating feed-in tariffs.

In order to further investigate significance of renewable power generation as potential business segment, we compared announced investment in renewable power generation with total CAPEX of selected companies (Table 3) in the period 2013-2018 since there are no data for CAPEX for the next five year period (this is a part of broader research of Ilic and Ponomarenko related to level of vertical integration and di-versification of CEE oil companies - Ilic, A. \& Ponomarenko, T. (2019). Role of vertical integration and diversification in strategies of CEE oil companies in circumstances of increased uncertainty and energy transition. Work in progres).

Some companies, for example PKN Orlen and Hellenic Petroleum, are planning strong investment in this segment both in absolute terms and in relative terms (as \% of CAPEX executed in the period 2013-2018), while Petrol and NIS have a bit moderate approach. For example, PKN Orlen is making preparations for an offshore wind farm project on the Baltic Sea with 1,200 MW of installed capacity which represent around 1/3 of CAPEX executed in the period 2013-2018. According to the 2018 annual report, Hellenic Petroleum plans to invest $€ 300-400$ in different renewables power production, which also represents $1 / 3$ of CAPEX in the period 2013-2018. Serbian oil company NIS is in the process of constructing wind farm with installed capacity of $102 \mathrm{MW}$, while Slovenian Petrol, already present in the renewables power generation, plans to add additional $20 \mathrm{MW}$ of installed capacities. On the other hand, OMV and MOL and their related parties, OMV Petrom and INA, are planning only symbolic investment in power generation based on renewables.

In addition, we compared investments of renewable power generation in relative terms with oil self-sufficiency in which oil sufficiency is defined as share of produced crude oil in total processed crude oil (Figure 1).

Companies that have lower crude oil self-sufficiency, such as PKN Orlen and Hellenic Petroleum, intend to significantly invest in renewables, while companies that have higher oil selfsufficiency, such as OMV and OMV Petrol, do not plan to substantially invest in renewables. Petrol and NIS also plan a substantial amount of investment in renewables, while MOL and INA remained focused on other business segments. Correlation coefficient between oil selfsufficiency and new CAPEX for renewables is relatively high at -0.61 indicating that 
Table 3. Planed new investment in renewable power generation.

\begin{tabular}{|c|c|c|c|c|c|c|}
\hline & $\begin{array}{l}\text { New power } \\
\text { RES cap**. } \\
\text { [MW] }\end{array}$ & $\begin{array}{l}\text { New power RES } \\
\text { CAPEX [€ mn]* }\end{array}$ & Type & $\begin{array}{l}\text { CAPEX } \\
13-18 \\
{[€ \mathrm{mn}]}\end{array}$ & $\begin{array}{l}\text { New power } \\
\text { RES CAPEX } \\
{[\% \text { CAPEX }} \\
13-18]\end{array}$ & $\begin{array}{l}\text { Oil self- } \\
\text { sufficiency } \\
2018\end{array}$ \\
\hline $\begin{array}{l}\text { PKN Orlen, } \\
\text { Poland }\end{array}$ & 1,200 & 1,800 & Wind & 5,414 & $33 \%$ & $1 \%$ \\
\hline $\begin{array}{l}\text { OMV, } \\
\text { Austria }\end{array}$ & 16 & 24 & Solar & 20,770 & $0 \%$ & $57 \%$ \\
\hline $\begin{array}{l}\text { MOL, } \\
\text { Hungary }\end{array}$ & 32 & 48 & $\begin{array}{l}\text { Solar/ } \\
\text { geothermal }\end{array}$ & 6,999 & $1 \%$ & $12 \%$ \\
\hline $\begin{array}{l}\text { Hellenic } \\
\text { Petrol., } \\
\text { Greece }\end{array}$ & 200 & 300 & Different & 905 & $33 \%$ & $0 \%$ \\
\hline $\begin{array}{l}\text { OMV } \\
\text { Petrom, } \\
\text { Romania }\end{array}$ & 0 & 0 & - & 5,625 & $0 \%$ & $99 \%$ \\
\hline $\begin{array}{l}\text { INA, } \\
\text { Croatia }\end{array}$ & 10 & 15 & $\begin{array}{l}\text { Solar/ } \\
\text { geothermal }\end{array}$ & 1,224 & $1 \%$ & $18 \%$ \\
\hline $\begin{array}{l}\text { Petrol, } \\
\text { Slovenia }\end{array}$ & 20 & 30 & Different & 434 & $7 \%$ & $0 \%$ \\
\hline NIS, Serbia & 102 & 140 & Wind & 1,855 & $8 \%$ & $24 \%$ \\
\hline Total & 1,580 & 2,357 & & 43,226 & $5 \%$ & $18 \%$ \\
\hline $\begin{array}{l}\text { Total con- } \\
\text { solidated }\end{array}$ & $\overline{1,570}$ & $\overline{2,342}$ & & $\underline{36,377}$ & $6 \%$ & $\overline{15 \%}$ \\
\hline
\end{tabular}

Source: Annual reports and official statements of selected companies

* Estimation of authors based on the type of investment

** RES - Renewables

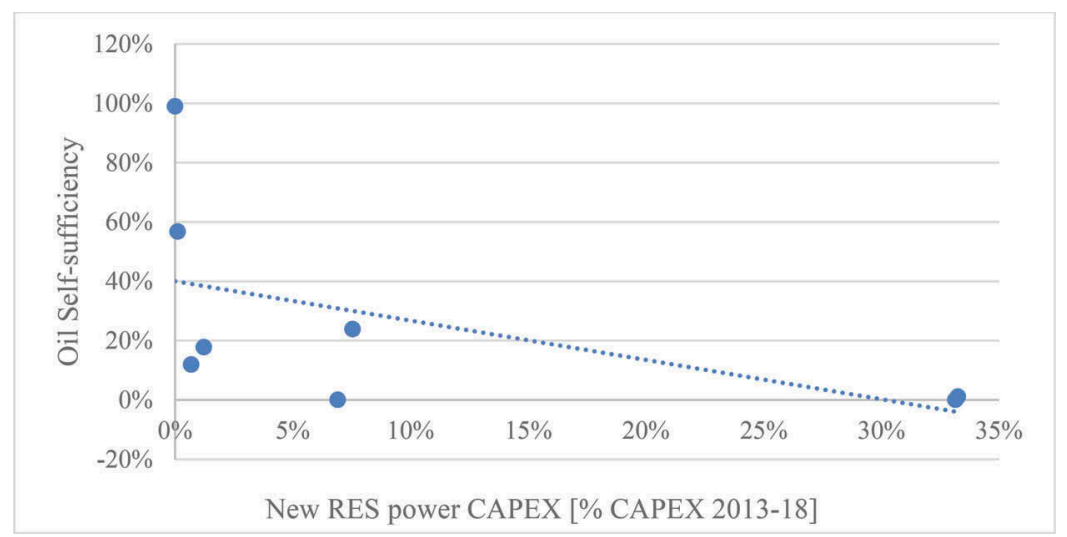

Figure 1. Dependence of investment in RES power and oil self-sufficiency.

Source: Annual reports of selected companies and estimations of authors

companies which have low or limited reserves and production of oil are more interested in power generation based on renewables. 


\section{CONCLUSION}

So far, the role of renewables in strategies of CEE oil companies has been relatively weak, even below the average of global oil companies. However, project started recently (for example, NIS's construction of wind farm of capacity of $102 \mathrm{MW}$ ) and recently announced projects (PKN Orlen's construction of wind farm) and potential realization of renewable projects of Hellenic Petroleum (still uncertain timing and the scope), with Petrol's existing and planned activities indicate an increased role of renewables in strategies of CEE companies. Our research showed, under the assumptions that announced projects will be realized, that: (1) level of investment in renewables of CEE companies in the future will be relatively high (around 5\% of CAPEX from the period 2013-2018), (2) there are strong differences among CEE oil companies in terms of the significance of renewable productions (PKN Orlen, Hellenic Petroleum, NIS and Petrol with relatively strong renewables and OMV and MOL and their related parties OMV Petrom and INA with only symbolic presence), (3) those oil companies with relatively weak upstream (crude oil reserves and production) are more interested in renewables (confirmed findings of (Pickl, 2019) based on the analysis of oil majors) and (4) production of electricity from wind and solar dominates the renewable activities of CEE oil companies. In addition to this, renewable segment in the portfolio of CEE oil companies is at an early stage of development with only a few projects ongoing.

It is obvious that decision on entering and developing renewables business segment is done at case-by-case basis without any generalization. Additionally, it seems that an oil company decides based on the estimation of its competitive advantages and the prospects to success in the specific environment. This specific environment encompasses: (1) regulation and expected regulatory changes (how regulatory bodies are strict to carbon reduction and how lucrative are the government incentives, which is the most likely reason why NIS started production of wind farm), (2) interest of shareholders and other stakeholders (how they are strict to promoting green energy, which was the case with transformation of Ørsted to a renewable-based company), (3) relative internal competences in electricity production (this was probably the case with PKN Orlen's intention to construct a big wind park since the company has strong position in power production from which it gets $15 \%$ of EBITDA), (4) resource availability at reasonable costs, primarily reserves of crude oil (the most likely reason why American companies and OMV are not focused on renewables), (5) expected changes of technology and its costs (keeping up with technology changes in order not to be late new energy revolution) and (6) expected change in customer preferences. However, this part of analyzing specific reasons for existence or non-existence of renewables in the strategies of oil companies deserves further investigations.

\section{REFERENCES}

Annual reports and other official documentations and press releases: PKN Orlen, OMV, MOL Group, Hellenic Petroleum, OMV Petrom, INA, Petrom, NIS [2013, 2014, 2015, 2016, 2017, 2018, 2019].

Cherepovitsyn, A. \& Ilinova, A. 2016. Ecological, Economic and Social Issues of Implementing Carbon Dioxide Sequestration Technologies in the Oil and Gas Industry in Russia. Journal of Ecological Engineering, volume 17. Issue 2. 19-23.

Csomos, G. 2014. Relationship between Large Oil Companies and the Renewable Energy Sector. Environment Engineering and Management Journal.

ExxonMobil. 2019. Outlook for Energy: A Perspective to 2040.

Fattouh, B., Poudineh, R. \& West, R. 2018. The Rise of Renewables and Energy Transition: What Adaptation Strategy for Oil Companies and Oil-Exporting Countries? The Oxford Institute for Energy Studies, Paper: MEP 19.

Fattouh, B., Poudineh, R. \& West, R. 2019. Energy Transition, Uncertainty, and the Implications of Change in the Risk Preferences of Fossil Fuel Investors. The Oxford Institute for Energy Studies, Energy Insight 45 OIES.

Gielen, D., Boshell, F., Saygin, D., Bazilian, M., Wagner. N. \& Gorini, R. 2019. The Role of Renewable Energy in the Global Energy Transformation. Energy Strategy Review 24. 
Ilic, A. \& Ponomarenko, T. 2019. Role of vertical integration and diversification in strategies of CEE oil companies in circumstances of increased uncertainty and energy transition. Work in progress.

Ilinova, A., Cherepovitsyn, A. \& Evseeva, O. 2018. Stakeholder Management: An Approach in CCS Projects. Resources 7(4) 83.

International Energy Agency. 2019. Global EV Outlook 2019: Scaling-up the Transition to Electric Mobility.

International Energy Agency. 2020. The Oil and Gas Industry in Energy Transition. Insights from IEA analysis.

International Renewable Energy Agency. 2019. Renewable Power Generation Costs in 2018, IRENA, Abu Dhabi.

Mojarad, A. A. S., Atashbari, V. \& Tantau, A. D. 2018. Challenges for Sustainable Development Strategies in Oil and Gas Industries. Conference paper, De Gruyter Open.

Pickl, M. 2019. The Renewable Energy Strategies of Oil Majors - From Oil to Energy. Energy Strategy Reviews 26.

Romasheva, N. \& Ilinova, A. 2019. CCS Projects: How Regulatory Framework Influences Their Deployment. Resources, No. 8.

Romasheva, N., Kruk, M. \& Cherepovitsyn, A. 2018. Propagation Perspectives of CO2 Sequestraction in the World. International Journal of Mechanical Engineering and Technology, volume 9, issue 11 $1877-1885$.

Shivakumar, A., Dobbins, A., Fahl, U. \& Singh, A. 2019. Drivers of Renewable Energy Deployment in the EU: An Analysis of Past Trends and Projections. Energy Strategy Reviews 26.

Tcvetkov, P., Cherepovitsyn, A. \& Fedoseev, S. 2019. Public Perception of Carbon Capture and Storage: A State-of-the-Art-Review. Heliyon 5 e02845.

West, R. \& Fattouh, B. 2019. The Energy Transition and Oil Companies' Hard Choices. The Oxford Institute for Energy Studies, Energy Insight 50.

Zhong, M. \& Bazilian, M. D. 2018. Contours of Energy Transition: Investment by International Oil and Gas Companies in Renewable Energy. The Electricity Journal 31. 